\title{
Emilia Olechnowicz
}

\section{„Ryszard II to ja”. \\ Teoria dwóch ciał króla \\ i elżbietańska praktyka polityczna}

\section{Wprowadzenie}

Ernst Kantorowicz rozpoczyna swoje Dwa ciała króla od rozdziału poświęconego Raportom Edmunda Plowdena. Ów XVI-wieczny angielski prawnik dowodził w nich, że król w chwili koronacji i namaszczenia świętymi olejami przestawał być zwykłym śmiertelnikiem, a zyskiwał udział w nadprzyrodzonej godności. Od tej chwili miał dwa ciała: śmiertelne ciało naturalne, podlegające ludzkim ułomnościom, i wspólnotowe ciało polityczne, pozbawione wieku, płci oraz „innych naturalnych skaz i niedojrzałości"1. Korporacyjny charakter tego ciała jest definiowany odmiennie od wspólnoty państwowej, którą Jan z Salisbury opisywał w Policraticusie jako organizm zorganizowany hierarchicznie, ale powiązany relacjami

Emilia Olechnowicz (ORCID 0000-0003-4874-3471) - adiunkt w Zakładzie Historii i Teorii Teatru Instytutu Sztuki Polskiej Akademii Nauk. Współpracuje z Kolegium Artes Liberales Uniwersytetu Warszawskiego, gdzie prowadzi konwersatorium „Szekspirowskie ciała”. Kontakt: eolechnowicz@ gmail.com

1 E. Plowden, Commentaries or Reports, S. Brooke, London 1816, s. 212a. Przekład polski cyt. za: E. Kantorowicz, Dwa ciała króla. Studium ze średniowiecznej teologii politycznej, przeł. M. Michalski, A. Krawiec, Wydawnictwo Naukowe PWN, Warszawa 2007, s. 6. 
współzależności, z królem jako głową i poddanymi jako członkami². Wspólnota, którą opisuje Plowden, obejmuje przede wszystkim przeszłych i przyszłych królów, a jest aktualizowana w osobie aktualnie panującego. W myśl teorii dwóch ciał wszyscy oni stanowią jedno mistyczne ciało, które jest nadrzędne wobec ciała naturalnego, konkretnego władcy ${ }^{3}$. Innymi słowy: król, wstępując na tron, miał się zrzec indywidualnej tożsamości - a wraz z nią prywatnych praw, przywilejów i upodobań - i stać się Królem ponadosobowym, tak aby dwa ciała zostały „wcielone w jednej osobie” i mogły stanowić „jedno Ciało bez rozróżnienia”. Władca i jego następca są więc jedną osobą: monarchą, który nigdy nie umiera. Warto zauważyć, że przeszłość nie jest tu - jak często w XVI- i XVII-wiecznej polityce modusem czy źródłem mitycznej genealogii. Przeciwnie - w myśl teorii dwóch ciał historia jest niejako unieważniona. Ciało polityczne monarchy funkcjonuje w wymiarze ponadhistorycznym: mamy tutaj do czynienia nie tyle z sukcesją, ile z nieprzerwanym trwaniem.

Plowden skodyfikował tę mistyczno-prawną koncepcję za panowania Elżbiety I, jednak ani Kantorowicz, ani znaczna część jego późniejszych komentatorów nie uwzględnia złożonych relacji między doktryną dwóch ciał a realiami elżbietańskiej polityki. Celem tego tekstu jest wskazanie, w jaki sposób owa koncepcja wpływała na praktykę polityczną oraz jej artystyczną reprezentację. Kantorowicz wskazuje, że koncept ciała politycznego służył wzmocnieniu pozycji monarchy i otoczeniu go symboliczną osłoną. Taką właśnie interpretację przyjmowano najczęściej w odniesieniu do XVI-wiecznej Anglii ${ }^{5}$. Tymczasem, jak dowodzi Marie Axton, juryści z kolegiów prawniczych próbowali ograniczyć prerogatywy królo-

2 Jan z Salisbury, Policraticus, przeł. M. Kruk, Verba, Lublin 2008.

3 Por. J.R. Rust, The Body in Mystery. The Political Theology of the Corpus Mysticum in the Literature of Reformation England, Northwestern University Press, Evanston 2014.

$4 \quad$ E. Plowden, Commentaries..., s. 213. Cyt. za: E. Kantorowicz, Dwa ciała..., s. 7.

5 Zob. m.in. L. Montrose, Elizabeth through the Looking Glass. Picturing the Queen's Two Bodies, w: The Body of the Queen, Gender and Rule in the Courtly World, 1500-2000, red. R. Schulte, Berghahn Books, New York 2006; S. Doran, The Queen, w: The Elizabethan World, red. S. Doran, N. Jones, Routledge, London 2011, s. 35-58; A. Whitelock, The Queen's Two Bodies. The Image and Reality of the Body of Elizabeth I, w: The Image and Perception of Monarchy in Medieval and Early Modern Europe, red. S. McGlynn, E. Woodacre, Cambridge Scholars Publishing, Cambridge 2014, s. 207-227. 
wej Elżbiety, wskazując na ponadosobowy charakter jej władzy ${ }^{6}$. Warto więc podkreślić, że w obraz króla jako jednoosobowej korporacji wpisany jest immanentny konflikt, wynikający nie tylko ze współistnienia w jednej osobie sprzecznych tożsamości, ale także z konieczności nieustannego negocjowania relacji między nimi. W związku z tym pojęcie dwóch ciał mogło służyć równocześnie jako narzędzie legitymizacji i kontestacji władzy. Paradoks ten dobrze obrazuje słynna deklaracja królowej „Ryszard II to ja"7, która od dekad intryguje badaczy i doczekała się obszernych komentarzy ${ }^{8}$. Dotychczas jednak nie usytuowano jej w kontekście doktryny dwóch ciał króla, w którym wybrzmiewa chyba najpełniej. Wpisana w nią perspektywa zniesionej czasowości pozwala spojrzeć w nowym świetle na utożsamienie królowej z Ryszardem II: zarówno historycznym władcą, jak i bohaterem Szekspirowskiej kroniki.

\section{Królowanie jako transgresja}

Elżbieta I od początku panowania posługiwała się konceptem dwóch ciał, który pozwalał na przekroczenie dwóch fundamentalnych problemów związanych z jej polityczną pozycją: płci oraz kwestionowanych praw do tronu ${ }^{9}$. Jako kobieta ${ }^{10}$ i córka Anny Boleyn, przez własnego ojca

6 M. Axton, The Queen's Two Bodies. Drama and the Elizabethan Succession, Royal Historical Society, London 1977.

7 J. Nichols, Progresses, Public Processions of Queen Elizabeth, t. 3, J. Nichols and Son, London 1823, s. 552-553.

8 Zob. m.in. J. Scott-Warren, Was Elizabeth I Richard II? The Authenticity of Lambarde's „Conversation”, "The Review of English Studies” 2013, t. 64, nr 264, s. 208-230; P.E.J. Hammer, Shakespeare's Richard II. The Play of 7 February 1601, and the Essex Rising, "Shakespeare Quarterly” 2008, t. 59, nr 1, s. 1-35; P. Raffield, Law and the Equivocal Image. Sacred and Profane in Royal Portraiture, w: Visualizing Law and Authority. Essays on Legal Aesthetics. Law and Literature, red. L. Dahlberg, De Gruyter, Berlin 2013, s. 51-73.

9 Por. M. Levine, The Early Elizabethan Succession Question, 1558-1568, Stanford University Press, Stanford 1966; K. Post Walton, The English Succession Crisis and Debates about Mary Stewart. Law, National Identity, Citizenship and the Queen's Two Bodies: w: eadem, Catholic Queen, Protestant Patriarchy, Palgrave Macmillan, London 2007, s. 49-88; A.N. McLaren, Political Culture in the Reign of Elizabeth I. Queen and Commonwealth 1558-1585, Cambridge University Press, Cambridge 2004, s. 12-74.

10 [J. Knox], First Blast of the Trumpet against the Monstrous Regiment of Women, w: The Works of John Knox, [J. Crespin, Geneva] 1558. Zob. też: The Image and Perception of Monarchy in 
odsunięta od prawa dziedziczenia aktem sukcesyjnym z 1536 roku ${ }^{11}$, ekskomunikowana przez papieża jako bękart i heretyczka, Elżbieta znalazła $\mathrm{w}$ doktrynie dwóch ciał potężne narzędzie legitymizacyjne ${ }^{12}$. Argumenty przeciwników dotyczyły bowiem cech jej ciała naturalnego, tymczasem ciało polityczne było nie tylko wolne od ułomności, lecz również tożsame z poprzednikami na tronie angielskim. Królowa akcentowała ciągłość angielskiej monarchii, by zaprezentować się jako prawomocna sukcesorka godności (Dignitas). Już w pierwszej mowie po objęciu tronu stwierdziła: „Choć mam tylko jedno ciało naturalne [bodye naturallye], to z jego dozwolenia otrzymuję teraz ciało wspólnotowe [bodye politique], by nim rządzić; i pragnę, byście wy wszyscy, moi Panowie (zwłaszcza Wy, szlachetnie urodzeni, każdy w swojej randze i sile) byli mi pomocni, abyśmy ja i moje rządy oraz wy i wasza pomoc spodobali się Wszechmogącemu Bogu"13. Pochodzące od Boga ciało polityczne miało zatem automatycznie gwarantować jej zdolność do sprawowania rządów. W mowie do wojsk w przededniu bitwy z hiszpańską Armadą Elżbieta scharakteryzowała relację dwóch ciał jako politycznego hermafrodytę, złożonego z żeńskiego ciała naturalnego i męskiego ciała politycznego. Mówiła: „Wiem, że mam ciało wątłej i słabej niewiasty. Ale mam też serce i żołądek króla, i to króla Anglii"14. W analogiczny sposób relację między dwoma ciałami króla zdefiniował XIV-wieczny włoski prawnik Baldus de Ubaldis, który pisał, że stanowi „jedność z dwóch skrajności”15 jak dwojaka płeć hermafrodyty. Elżbieta świadomie przekraczała więc nie tylko linearną chronologię, ale także ustalone role płciowe i społeczne. W 1593 roku w mowie parlamentarnej miała powiedzieć: „[...] to królestwo miało wielu szlachetnych i zwycięskich władców. Pod względem mądrości, pomyślności i innych

Medieval and Early Modern Europe, red. S. McGlynn, E. Woodacre, Cambridge Scholars Publishing, Newcastle upon Tyne 2014.

11 Tudor Constitutional Documents. A.D. 1485-1603, red. J.R. Tanner, Cambridge University Press, Cambridge 1930, s. 389, 397.

12 Por. T. Booth, A Body Politic to Govern. The Political Humanism of Elizabeth I, Cambridge Scholars Publishing, Newcastle upon Tyne 2013.

13 The National Archives, PRO, State Papers Domestic Elizabeth SP 12/1/7; Elizabeth I, Collected Works, red. L.S. Marcus, J. Mueller, M.B. Rose, University of Chicago Press, Chicago 2000, s. 51.

14 The British Library, Harley 6798, f. 87.

15 Corpus Iuris Civilis, t. 1, Venezia 1584, 5, 10. Cyt. za: E. Kantorowicz, Dwa ciała..., s. 8. 
cnót nie będę się z nimi równać, ale [...] co się tyczy miłości, troski, szczerości i sprawiedliwości, mogę się równać z każdym władcą, którego dotąd mieliście lub kiedykolwiek mieć będziecie"16. Sugerowała w ten sposób, że za powodzeniem jej rządów stoi umiejętność łączenia dwóch - pozornie sprzecznych - ról: monarchy i matki. Jeśli królewskie ciało łączono zawsze z płodnością podległych mu ziem, ona kreowała swój wizerunek jako matki poddanych deklarując, że po jej śmierci „mogą mieć wiele macoch, ale nie będą mieć prawdziwszej matki [a more natural mother]"17 niż ona sama. Poddani byliby więc dziećmi zrodzonymi z ciała politycznego królowej - jej politycznym potomstwem ${ }^{18}$. W ten sposób przekuwała to, co mogło być postrzegane jako niedostatek - pozycję niezamężnej kobiety, niezdolnej dać królestwu dziedzica - w polityczną personę Królowej-Dziewicy ${ }^{19}$. Z zachowanych relacji wynika, że istotnie była postrzegana jako figura dwupłciowa ${ }^{20}$. Przedstawiciel Izby Gmin zwracał się do Elżbiety słowami: „Błagamy Jej Wysokość o opiekę króla i miłość matki, by nią otoczyła nas, swoich poddanych i dzieci"21. Arcybiskup Yorku, Nicholas Heath, opisywał królową jako „naszego władcę i władczynię, naszego króla i królową, naszego cesarza i cesarzową"22. Za sprawą nieustannego przekraczania ról społecznych Elżbieta stała się postacią budzącą podziw, lecz również niepokój. Po śmierci królowej Robert Cecil w liście do Johna Haringtona opisał jej paradoksalną tożsamość płciową następująco:

16 The British Library, MS Cotton Titus F.II, fols. 98v-99v. Elizabeth I, Collected Works..., s. 329.

17 The National Archives, PRO, State Papers Domestic, Elizabeth 12/27/37, fol. 154v; Elizabeth I, Collected Works..., s. 72.

18 M. Axton, The Queen's Two Bodies..., s. 38-39.

19 L. Montrose, The Subject of Elizabeth, The University of Chicago Press, Chicago 2006; P. Johnson, Elizabeth I. A Study in Power and Intellect, Weidenfeld \& Nicholson, London 1974; L. Shenk, Learned Queen. The Image of Elizabeth I in Politic and Poetry, Palgrave Macmillian, New York 2010.

20 C. Levin, The Heart and Stomach of a King. Elizabeth I and the Politics of Sex and Power, The University of Pennsylvania Press, Philadelphia 1994, s. 121-148.

21 T.E. Hartley, Proceedings in the Parliaments of Elizabeth I, t. 1, Leicester University Press, Leicester 1981, s. 157.

22 Hethe, Archebishoppe of Yorke his Oration Made in the Parliament House, 1559, w: Annals of the Reformation and Establishment of Religion, and Other Various Occurrences in the Church of England, during Queen Elizabeth's Happy Reign, red. J. Strype, Clarendon, Oxford 1824, s. 399. 
„była więcej niż mężczyzną i, szczerze mówiąc, czasami także mniej niż kobietą"23.

Metafora dwóch ciał wyraża stan idealnej równowagi między królem i królestwem. Marie Axton zwraca uwagę, że był to ideał trudny do zrealizowania, a niemożliwy do utrzymania ${ }^{24}$. Pojęcie ciała politycznego bywało wykorzystywane do ograniczenia władzy królowej, zmniejszenia jej wpływu na politykę królestwa. Dobrze pokazuje to sprawa księstwa Lancaster, która w 1561 roku stanęła przed sądem królewskim. Małoletni Edward VI wydzierżawił część tych ziem, a Elżbieta po dojściu do władzy chciała jego decyzję unieważnić uzasadniając, że jej przyrodni brat i poprzednik był za młody, aby podjąć w tej sprawie trafną decyzję. Sędziowie rozstrzygnęli spór wbrew woli królowej argumentując, że wprawdzie ciało naturalne króla było małoletnie, ale jego ciało polityczne „usuwa niedoskonałości ciała naturalnego” ${ }^{25}$ i dlatego „to, co czyni Król w ciele wspólnotowym nie może zostać unieważnione albo udaremnione ze względu na upośledzenie jego ciała naturalnego"26. Innymi słowy: decyzji króla nie można odwołać, ponieważ król nigdy nie umarł. Użyli zatem tego samego argumentu, którym posługiwała się Elżbieta, ale w odwrotnym celu: aby pokreślić ponadosobowy charakter władzy monarszej, uchylając tym samym osobiste decyzje królowej ${ }^{27}$. Jeśli Elżbieta chciała projektować obraz dwóch ciał królewskich w harmonijnej unii, zdaniem jurystów ich relacja była odmienna, bo oparta na całkowitym podporządkowaniu ciała naturalnego ponadosobowemu ciału politycznemu. Plowden podkreśla, że ciało polityczne nieodwracalnie zmienia (altereth) sytuację ciała natu-

23 Nugae Antiquae Being a Miscellaneous Collection of Original Papers, in Prose and Verse, t. 1, red. J. Harrington, Vernor and Hood, London 1804, s. 345.

M. Axton, The Queen's Two Bodies..., s. 11-25.

E. Plowden, Commentaries..., s. 213a; E. Kantorowicz, Dwa ciała..., s. 7.

E. Kantorowicz, Dwa ciała..., s. 6.

Kilka lat później królowa toczyła podobny spór z earlem Northumberlandem. Jego prawnicy zakwestionowali prawo królowej do ziem w Newlands i znajdujących się w nich złóż, podczas gdy reprezentant królowej dowodził, że prawo królowej pochodzi z boskiego nadania. Sędziowie rozstrzygnęli spór na korzyść królowej, co Plowden surowo skrytykował jako nadużycie. Zob. C. Sale, "The King is a Thing". The King's Prerogative and the Treasure of the Realm in Plowden's Report of the Case of Mines and Shakespeare's Hamlet, w: Shakespeare and the Law, red. P. Raffield, G. Watt, Hart Publishing, Oxford 2008, s. 136. 
ralnego, pozbawiając je na przykład możliwości sporządzenia testamentu, ponieważ w chwili śmierci król traci prawa do ziem, które przejmuje już jego następca ${ }^{28}$. Elżbietańscy prawnicy odwoływali się zatem do pojęcia dwóch ciał, aby ograniczać prerogatywy władcy, co dobrze pokazuje, że nowożytna angielska monarchia nie stanowi przykładu suwerennej władzy, jak definiuje ją Carl Schmitt ${ }^{29}$, a relacje króla z państwem były przedmiotem nieustannych negocjacji. Metafora dwóch ciał była użytecznym, ale ambiwalentnym narzędziem politycznym, mogącym uprawomocnić zarówno absolutyzm, jak i królobójstwo ${ }^{30}$. Odwoływano się do niej, by dowodzić przeciwstawnych racji, ale też stosowano ją wybiórczo: tam, gdzie pozór niezakłóconego trwania był korzystny dla interesów monarchy lub państwa. Warto podkreślić, że mamy tu do czynienia właśnie z pozorem, konstruktem fikcyjnym. W czasach Szekspira, jak przekonująco dowodzi Lorna Hutson, król nie jest już bowiem ani uosobieniem państwa, które zaczyna funkcjonować jako samodzielny byt pojęciowy, ani wcieleniem sprawiedliwości, która funkcjonuje jako suwerenny, odrębny od króla organizm $^{31}$.

28 State Papers sygn. 12/36/34, fol. 6v. Cyt. za: ibidem, s. 144. Henrykowi VIII prawa do wyznaczenia w testamencie następcy udzielił specjalnym aktem prawnym Parlament. Por. M. Axton, The Influence of Edmund Plowden's Succession Treatise, „Huntington Library Quarterly” 1974, t. 37, nr 3, s. 220.

29 Zob. C. Schmitt, Teologia polityczna. Cztery rozdziaty poświęcone nauce o suwerenności, w: idem, Teologia polityczna $i$ inne pisma, przeł. M.A. Cichocki, Aletheia, Warszawa 2012, s. 33-83. Kantorowiczowski wariant teologii politycznej konfrontują ze Schmittowskim między innymi V. Kahn, Political Theology and Fiction, „Representations” 2009, nr 1, s. 77-101; A. Höfele, No Hamlets, German Shakespeare from Friedrich Nietzsche to Carl Schmitt, Oxford University Press, Oxford 2016, s. 108-109; M. Herrero, On Political Theology. The Hidden Dialogue between C. Schmitt and Ernst H. Kantorowicz in „The King's Two Bodies”, „History of European Ideas" 2015, t. 41, nr 8, s. 1164-1177. Por. też D. Norbrook, The Emperor's New Body? "Richard II", Ernst Kantorowicz, and the Politics of Shakespeare Criticism, „Textual Practice” 1996, nr 10, s. 329-357.

30 L. Hutson, Not the King's Two Bodies. Reading the "Body Politic” in Shakespeare's Henry IV, cz. 1-2, w: Rhetoric and Law in Early Modern Europe, red. V.A. Kahn, L. Hutson, Yale University Press. New Haven 2001, s. 168.

31 L. Hutson, Imagining Justice, Kantorowicz and Shakespeare, „Representations”, 2009, t. 106, nr 1, s. 118-142. 


\section{Król jako persona ficta}

W myśl teorii dwóch ciał panujący monarcha stawał się reprezentantem niewidzialnej, bezczasowej korporacji, złożonej z królów zmarłych oraz tych, którzy się jeszcze nie narodzili. Tę bezcielesną wspólnotę, personifikowaną przez władcę, określano mianem persona ficta (osoby fikcyjnej) i definiowano jako "mnogość ludzi zebranych w jedno ciało" ${ }^{32}$. Określenie „fikcyjna” nie stanowi tu przeciwieństwa słowa „prawdziwa” skoro, zgodnie z formułą Baldusa: „[...] fikcja naśladuje naturę. Dlatego fikcja znajduje się tylko tam, gdzie może znajdować się prawda"33. Opozycja między fikcją a realnością w XVI-wiecznej Anglii nie opisuje wykluczających się możliwości, lecz raczej dwa bieguny magnetyczne organizujące świat - przede wszystkim świat władzy. Elżbietańska teoria i praktyka polityczna zawierała silny aspekt fikcjonalny, obecny w metaforze dwóch ciał ${ }^{34}$. Panowanie Elżbiety, tak jak wszystkie nowożytne monarchie, sięga po środki teatralne, aby inscenizować ciągłość i świętość władzy ${ }^{35}$. Związek między sztuką sprawowania rządów (statecraft) i sztuką sceniczną (stagecraft) wydawał się nierozerwalny: sądzono, że władza musi sięgać po atrybuty siły, by skutecznie siłę performować. Królom - od wstąpienia na tron aż po pogrzeb - towarzyszyły obrzędy i widowiska projektujące oraz utwierdzające ich władzę, ceremonialne formy „poprzez które królowie biorą symbolicznie w posiadanie swoje królestwo" ${ }^{36}$. Pompa uroczystości nie tylko repre-

32 E. Kantorowicz, Dwa ciała..., s. 245.

33 Ibidem.

34 Por. V. Kahn, Political Theology..., s. 84-85.

35 Por. m.in. M. Bloch, Królowie cudotwórcy. Studium na temat nadprzyrodzonego charakteru przypisywanego władzy królewskiej zwłaszcza we Francji $i$ w Anglii, przeł. J.M. Kłoczowski, Volumen - Bellona, Warszawa 1998; J.M. Saslow, The Medici Wedding of 1589. Florentine Festival as Theatrum Mundi, Yale University Press, New Haven 1996; S. Orgel, Illusion of Power, University of California Press, Berkeley 1974; L. Tennenhouse, Power on Display. The Politics of Shakespeare's Genres, Methuen, New York 1986, s. 72-101; U. Kizelbach, The Pragmatics of Early Modern Politics. Power and Kingship in Shakespeare's History Plays, Rodopi, Amsterdam - New York 2014.

36 C. Geertz, Centra, królowie, charyzma, w: idem, Wiedza lokalna. Dalsze eseje z zakresu antropologii interpretatywnej, przeł. D. Wolska, Wydawnictwo Uniwersytetu Jagiellońskiego, Kraków 2005, s. 130. 
zentuje władzę, ale także ją generuje ${ }^{37}$. Elżbieta - władczyni pozbawiona przecież scentralizowanej administracji czy stałej armii ${ }^{38}$ - posługiwała się widowiskami jako narzędziem sprawowania społecznej kontroli. Jej władza była „ustanawiana podczas teatralnych celebracji monarszej chwały oraz teatralnych aktów przemocy zsyłanej na wrogów tej chwały" ${ }^{39}$. W taki sposób urzeczywistniana zwierzchność mimowolnie ujawnia swoją słabość. Zakładając królowi teatralną maskę bóstwa zdradza, że „suweren jest panem stworzeń, ale też sam stworzeniem pozostaje" ${ }^{" 40}$. Wydaje się wręcz, że im bardziej problematyczna jest pozycja polityczna władców, tym silniejszą władzę performatywną sprawują ${ }^{41}$.

Związek między widowiskami a władzą ma charakter istotowy: sama władza jest rodzajem widowiska. W mowie do Parlamentu w 1586 roku Elżbieta stwierdziła: „my, książęta, powiadam wam, stoimy na scenie, na widoku i wśród spojrzeń całego świata; oczy wielu przyglądają się naszym czynom, plama na naszym odzieniu rychło zostanie wyśledzona, skaza w naszym działaniu - szybko dostrzeżona" ${ }^{\text {"2 }}$. Podobny obraz władzy nakreślił następca Elżbiety, Jakub I, który napominał syna: „Król niczym aktor jest na scenie, którego najdrobniejszym gestom i działaniom lud bacznie się przygląda. Dlatego też [...] lud, który zewnętrzną jedynie dostrzega powłokę, o naturze rzeczy zawsze podług [pozorów] mniemał będzie"43. Jak widzimy, konstatacja o teatralności władzy - a dokładniej: o analogii

37 L. Montrose, „Shaping Fantasies”. Figurations of Gender and Power in Elizabethan Culture, w: Representing the English Renaissance, red. S. Greenblatt, University of California Press, Berkeley 1988, s. 31-64.

38 S. Greenblatt, Niewidzialne kule. Władza i jej obalenie w dobie rensesansu, przeł. J. Sadowska, A. Szwach, K. Williams, „Dialog” 2010, nr 5 (55), s. 129.

39 Ibidem.

40 W. Benjamin, Źródta dramatu żałobnego w Niemczech, przeł. A. Kopacki, Wydawnictwo Sic!, Warszawa 2013 s. 92.

41 Richard Halpern dostrzega analogiczną zależność między pozycją polityczną szekspirowskiego Ryszarda II a jego władzą poetycką. Zob. R. Halpern, The King’s Two Buckets. Kantorowicz, Richard II, and Fiscal Trauerspiel, „Representations” 2009, t. 106, nr 1, s. 74.

42 A Report of Her Majestie's Most Gratious Answere, Delivered by Her selfe verbally, to the First Petitions of the Lords and Commons ... the xii Day of November 1586, w: A Collection of Scarce and Valuable Tracts, t. 1, red. W. Scott, wyd. T. Cordeil and W. Davies, London 1809, s. 220.

43 Jakub VI Stuart, Basilikon Doron, przeł. M. Misztal, Wydawnictwo Naukowe Akademii Pedagogicznej, Kraków 2006, s. 133 (przekład zmodyfikowany). 
między królem a aktorem - zawiera w sobie przestrogę czy naukę moralną, ale w niczym nie umniejsza powagi władcy. Monarcha może zatem być jednocześnie namaszczonym królem i aktorem odgrywającym rolę króla dla swoich poddanych. Między tymi powinnościami nie ma sprzeczności, przeciwnie - fikcja i rzeczywistość przenikają się i dopełniają nawzajem. W przywołanych wyżej słowach Elżbieta powtarza rzeczownik konotujący widzenie (in the sight and view), z kolei Jakub akcentuje uporczywość spojrzeń widzów-poddanych (people gazingly do behold). Wydaje się więc, że to właśnie widzialność jest przestrzenią działania i naturalną domeną władzy. Poddani, tak jak widzowie w teatrze, $\mathrm{z}$ jednej strony musieli być zaangażowani w tę „uprzywilejowaną widzialność”44, z drugiej zaś byli zobowiązani „zachowywać odpowiedni, pełen szacunku dystans” ${ }^{45}$. Historyczny Ryszard II, jak opisuje kronikarz, „odprawiwszy królewskie rytuały, nakazywał przygotować sobie w komnacie tron, na którym publicznie zasiadał po wieczerzy i pozostawał tak aż do nieszporów, do nikogo się nie odzywając, a wszystkich obserwując, a gdy na kimś spoczął jego wzrok, ten człowiek - niezależnie od rangi - musiał przyklęknąć przed królem"46. Królewski aktor staje się tu najważniejszym widzem, nie tracąc swojej władzy. Jej instrumentem jest tutaj wzrok króla, który sprawia, że poddani zobowiązani są do złożenia hołdu. Ten fragment kroniki bywa interpretowany jako dowód tyrańskich skłonności Ryszarda II. Z pewnością świadczy o tym, że władzy nieodłącznie towarzyszy tyrania spojrzeń. W jej ramach król jest tym, który jest widziany oraz tym, który patrzy, nigdy nie mogąc umknąć spojrzeniom ${ }^{47}$. Nawet po śmierci ciało króla było przedmiotem spojrzeń. Anonimowy kronikarz zanotował, że zwłoki Ryszarda II były obwożone po kraju, aby poddani „mogli zobaczyć i odróżnić go od innych [myghte se and knowe his persone from olle othir]"48, jak gdyby

44 S. Greenblatt, Niewidzialne kule..., s. 129 (przekład zmodyfikowany).

45 Ibidem.

46 Chronicles of the Revolution, 1397-1400. The Reign of Richard II, red. C. Given-Wilson, Manchester University Press, Manchester 1993, s. 68.

47 Por. R. Ashby, „Pierced to the Soul”. The Politics of the Gaze in "Richard II”, ,Shakespeare” 2015, t. 11, nr 2, s. 201-213.

48 An English Chronicle of the Reigns of Richard II, Henry IV, Henry V, and Henry VI, red. J.S. Davies, Camden Society, London 1856, s. 21. Cyt. za: E. Vyroubalová, J.R. Wood, Propping up the King's Two Bodies in „Richard II”, „Early English Studies” 2011, nr 4, s. 18-19. 
na dowód, że ciało naturalne króla jest martwe, a ciało polityczne żyje w osobie następcy.

W ramach królewskiej strategii autoprezentacji Elżbieta ukazywała się poddanym pod postacią istoty nadprzyrodzonej: jako bogini Księżyca Diana, pod postacią quasi-mitologicznej persony Gloriany czy jako dziewicza bogini sprawiedliwości Astrea z mesjanistycznej bukoliki Wergiliu$\mathrm{sza}^{49}$. Epifanie królowej-bogini przybierały postać literackich i malarskich reprezentacji lub widowisk dworskich i wszystkie operowały hiperbolą. Ukazywały królową jako władczynię już nie tylko Anglii, nie Europy, nie świata nawet - ale panujące nad wszechświatem bóstwo, „księcia światła, Słońce [The prince of light. The Sonne]" ${ }^{50}$. W ten sposób dokonywała się transgresja nie tylko czasu i płci, lecz również statusu ontologicznego: Elżbieta nie jest już człowiekiem, ale kosmicznym zjawiskiem czy wcieloną ideą. Królowa ukazywała się poddanym jako bogini Astrea, najzupełniej dosłownie „odziana w sprawiedliwość” ${ }^{1}$. W elżbietańskiej Anglii na poziomie politycznego spektaklu dokonuje się więc to, co nie udaje się jako mistyczno-prawna spekulacja za panowania Ryszarda II: wyobrażenie króla jako uosobionej sprawiedliwości ${ }^{52}$. To utożsamienie może być jednak ustanowione tylko na poziomie fikcjonalnym, a konstruowane w ten sposób wyobrażenie lex animata przypomina raczej ruchomą figurę teatralną niż ikonę boskiej sprawiedliwości. Przywodzi na myśl naturalnej wielkości drewniane wizerunki, ubierane w królewskie szaty i obwożone w czasie pogrzebu na dowód, że król nigdy nie umiera.

49 Zob. F.A. Yates, Queen Elizabeth as Astraea, „Journal of the Warburg and Courtauld Institutes" 1947, t. 10, s. 27-82. Por. także F.A. de Armas, The Return of Astraea. An Astral-Imperial Myth in Calderón, The University Press of Kentucky, Lexington 1986.

50 Tak brzmi pierwszy wers sonetu towarzyszącego wizerunkowi królowej na portrecie z Ditchey, dziś w National Portrait Gallery w Londynie (NPG 2561). Por. S. Frye, Elizabeth I. The Competition for Representation, Oxford University Press, Oxford 1993; A. Riehl, The Face of Queenship. Early Modern Representations of Elizabeth I, Palgrave Macmillan, New York 2010.

51 Frances Yates zwraca uwagę na portret królowej z 1598 roku, zachowany w Dover, na którym została ona ukazana w otoczeniu cnót teologicznych i kardynalnych, wśród których centralne miejsca zajmuje Sprawiedliwość, ubrana w taką samą czerwoną suknię jak królowa. F. Yates, Queen Elizabeth..., s. 62.

52 E. Kantorowicz, Dwa ciała..., s. 120. Zob. też P. Raffield, Representing the Body of Law in Early Modern England, w: Performing the Renaissance Body. Essays on Drama, Law, and Representation, red. J. Drakakis, S. Fiorato, De Gruyter Verlag, Berlin 2016, s. 135-144. 


\section{Kryzys i kontrola}

Ryszard II byłby zatem jedną z wielu masek, które przybierała Elżbieta I, aby wyrazić jakiś aspekt swojej władzy. Jest to jednak maska szczególna, bo zamiast kryć słabość i transponować ją w pozór siły - wprost ją ujawnia. Królowa miała sześćdziesiąt osiem lat, kiedy w rozmowie $\mathrm{z}$ Williamem Lambarde'em, archiwistą i prawnikiem z Lincoln's Inn, wypowiedziała słowa „Ryszard II to ja”. Nie wyznaczyła następcy, a nierozwiązana kwestia sukcesji rodziła coraz większe napięcia społeczne. Anglia znajdowała się w stanie wojny z Hiszpanią i z Irlandią, gdzie w 1593 roku wybuchł bunt przeciw Koronie. Na poddanych nakładano kolejne podatki w celu sfinansowania armii. Administracja państwowa od lat dziewięćdziesiątych XVI wieku pogrążała się w kryzysie ${ }^{53}$ : o posłuch starzejącej się królowej rywalizowały frakcje prowadzące między sobą wyniszczającą walkę. Efektywne sprawowanie władzy dodatkowo utrudniały wpływy kolejnych faworytów królowej, zyskujących nie tylko przywileje prywatne, ale także pozycję na scenie politycznej. Słowa „Ryszard II to ja” zostały więc wypowiedziane w czasie głębokiego kryzysu politycznego w państwie.

Wyznanie królowej odnosi się wprost do wydarzeń, które wyznaczają punkt kulminacyjny tego kryzysu, a które rozegrały się w Londynie pół roku wcześniej: do zbrojnego powstania Essexa z lutego 1601 roku. Dwa lata wcześniej faworyt królowej, Robert Devereux hrabia Essex, został mianowany namiestnikiem Irlandii i wysłany na czele armii, aby położyć kres trwającym tam walkom. W tej roli pojawia się zresztą, choć nienazwany wprost, w finalnym akcie Szekspirowskiego Henryka V. Przyszły buntownik i zdrajca jest tu opiewany jako bohater:

Gdyby namiestnik wdzięcznej pani naszej

Z Irlandii wrócił (a da Bóg, że wróci),

Na szabli ostrzu niosąc bunt przebity,

Ileż tysięcy ze spokojnych ulic

Biegłoby witać drogiego zwycięzcę?5 .

53 P.E.J. Hammer, Shakespeare's Richard II..., s. 4

54 W. Shakespeare, Życie Henryka V, przeł. L. Ulrich, w: idem, Dzieła dramatyczne, t. 3, Państwowy Instytut Wydawniczy, Warszawa 1973, s. 530-531. 
Niedługo po wystawieniu Henryka $V$ Essex istotnie powrócił do Londynu, ale nie na czele triumfalnego pochodu, lecz jako przegrany. Więcej - jako buntownik, bo wbrew rozkazom królowej zdecydował się wycofać swoje oddziały z Irlandii. Popadł tym samym w niełaskę, a nieprzychylni mu członkowie Tajnej Rady zaczęli nakłaniać królową do ukrócenia samowoli jej dawnego ulubieńca. Pod ich wpływem Essexa zatrzymano $\mathrm{w}$ areszcie domowym i odebrano mu przywileje, w tym główne źródło dochodu - monopol na produkcję słodkich win. Essex zdecydował się na desperacki czyn: wraz z grupą możnych zawiązał spisek wymierzony przeciw członkom królewskiej Tajnej Rady, ale być może mający także na celu zmuszenie królowej do abdykacji. Ósmego lutego 1601 roku wraz z niewielkim oddziałem Essex wkroczył do Londynu, nawołując mieszkańców do powstania przeciw władzy dworu. Masowa rebelia jednak nie wybuchła, a szczupłe siły buntowników zostały zmuszone do odwrotu. Wieczorem tego samego dnia Essex i jego wspólnicy zostali aresztowani pod zarzutem zdrady stanu i postawieni przed sądem. W dniu 25 lutego 1601 roku Essex został stracony w Tower, czyniąc zadość systematyce kar wyłożonej przez Lambarde'a w dziele Eirenarcha ${ }^{55}$.

W tej historii nieudanego rokoszu jest jeden element zasługujący na szczególną uwagę. Kilka dni przed wybuchem buntu wysłannicy Essexa zwrócili się do Sług Lorda Szambelana, szekspirowskiej kompanii teatralnej, prosząc o wystawienie sztuki „o obaleniu i zabiciu króla Ryszarda II”. Aktorzy ociągali się, wymawiając się, że to stara sztuka (Ryszard II miał premierę sześć lat wcześniej), ale ostatecznie przekonało ich honorarium: obiecano im „czterdzieści szylingów więcej niż zazwyczaj”56 - ta dodatkowa zapłata wynosiła dwukrotność zwykłego honorarium trupy ${ }^{57}$. W dniu 7 lutego 1601 roku, w przeddzień wybuchu powstania, spiskowcy (choć bez Essexa) przepłynęli łodzią Tamizę, aby obejrzeć w teatrze "Globe”

55 W. Lambarde, Eirenarcha, or of the Office of the Iustices of Peace in Two Bookes, Imprinted by Newbery, and Bynneman, London 1581. Zob. też: H. Keyishian, Punishment Theory in the Renaissance. The Law and the Drama, w: Shakespeare and the Law..., s. 175-184.

56 Practices and Treasons Attempted and Committed by Robert, Earl of Essex, and His Complices, London 1601, fol. K3r.

57 East Sussex Record Office, Brighton, Chamberlain's Accounts, 1593-1606, RYE 60/10, fol. $56 \mathrm{v}-57 \mathrm{r}$. 
Szekspirowskiego Ryszarda II. Dlaczego strategiczny ostatni wieczór przed atakiem garstka nieprzygotowanych buntowników zdecydowała się spędzić w teatrze? Dlaczego z taką determinacją dążyła do wystawienia właśnie tej sztuki? Wśród bardzo szczegółowych zeznań procesowych brakuje informacji na ten temat, bo też nikt nie postawił uczestnikom rebelii takiego pytania - nawet earlowi Southamptonowi, który był patronem trupy. Można zatem sądzić, że wybór Ryszarda II nie był zaskoczeniem, a motywacje spiskowców były tak jasne, że nie wymagały komentarza. Potwierdza to rozmowa królowej z Williamem Lambarde'em. Obojgu wzmianka o Ryszardzie II automatycznie przywodzi na myśl bunt Essexa, a postać historycznego króla - Szekspirowskiego bohatera. „Czterdzieści razy grano tę sztukę na ulicach i w domach”58 - skarżyła się Lambarde'owi królowa i nawet przyjmując, że liczebnik czterdzieści nie wskazuje rzeczywistej liczby przedstawień, ale oznacza tylko „wiele razy"59, musimy zwrócić uwagę, że Ryszard II staje się „tą sztuką”: utworem niemal jawnie wywrotowym, automatycznie kojarzonym z demistyfikacją władzy, a przy tym definiującym przestrzeń publiczną Londynu jako obszar dyskursu politycznego ${ }^{60}$.

Subwersyjny potencjał Ryszarda II musiał być dla królowej i jej otoczenia czytelny, skoro sztuka została ocenzurowana: jej trzy pierwsze wydania - wszystkie, które opublikowano za życia królowej Elżbiety - ukazały się bez problematycznego aktu czwartego ${ }^{61}$. Warto podkreślić, że cenzurowano nie reprezentację królobójstwa $(\mathrm{V}, 2)$, ale scenę abdykacji króla $(I V, 1)$, ukazaną jako dramatyczna ekstrakcja ciała naturalnego z ciała poli-

58 J. Nichols, Progresses..., s. 552.

59 P. Hammer, Shakespeare's Richard II..., s. 24.

60 Zob. J.S. Doty, Shakespeare's Richard II. „Popularity”, and the Early Modern Public Sphere, „Shakespeare Quarterly" 2010, t. 61, nr 2, s. 183-205. Por. też: D. Norbrook, A Liberal Tongue, Language and Rebellion in "Richard II", w: Shakespeare's Universe. Renaissance Ideas and Conventions. Essays in Honour of W.R. Elton, red. J.M. Mucciolo, S.J. Doloff, E.A. Rauchert, Scholar's Press, Aldershot 1996, s. 37-51.

61 J. Clare, The Censorship of the Deposition Scene in "Richard II", „The Review of English Studies” 1990, t. 41, s. 89-94; C.S. Clegg, "By the Choise and Inuitation of al the Realme." "Richard II" and Elizabethan Press Censorship, „Shakespeare Quarterly” 1997, t. 48, nr 4, s. 432-448. Por. też: G. Walker, The Politics of Performance in Early Renaissance Drama, Cambridge University Press, Cambridge 1998, s. 6-50. 
tycznego władcy. W doktrynie dwóch ciał śmierć króla określano mianem „przeniesienia” (demise), podczas którego majestat płynnie przechodził ze zmarłego poprzednika na władcę obejmującego tron. W Ryszardzie II to przeniesienie dokonuje się w scenie abdykacji, ona jest więc w porządku symbolicznym prawdziwą śmiercią króla, co czujnie wychwyciła elżbietańska cenzura. Dwudziestego czwartego lutego 1601 roku, w przeddzień egzekucji Essexa, Słudzy Lorda Szambelana ponownie odegrali Ryszarda II, tym razem na dworze - w symbolicznym akcie odzyskania kontroli nad aktorami, nad Szekspirowską historią czy może nad historią w ogóle ${ }^{62}$.

\section{Korona jako narzędzie tortur}

Szekspirowska historia Ryszarda II, którą Ernst Kantorowicz określił mianem „tragedii dwóch ciał króla” ${ }^{63}$, reprezentuje i zderza dwa mechanizmy polityczne: legitymizacji i kontestacji władzy. Ryszard sprawuje rządy w przeświadczeniu, że władza ufundowana na autorytecie religijnym jest nietykalna. Wbrew jednak samozapewnieniom króla, że „Nie dość jest wody w oceanach świata / By olej zmyć z pomazanego króla" ${ }^{64}$ okazuje się, że poddani mogą skutecznie zakwestionować jego władzę i zmusić go do ustąpienia z tronu. Wina Ryszarda polega na mylnym zrozumieniu własnej roli w królestwie: widzi siebie jako boskiego namiestnika, vicarius Dei, gdy tymczasem jest zarządcą skarbu, vicarius fisci ${ }^{65}$. Sądzi, że jest „zastępcą Bożym na ziemi”"66 i w konsekwencji stawia swoją wolę ponad prawem, własny interes ponad dobrem poddanych. W ten sposób staje się tyranem: zagrożeniem dla królestwa, a nie jego uosobieniem. W Szekspirowskim tekście zarzut ten formułuje Jan z Gandawy słowami:

62 Por. S. Greenblatt, Niewidzialne kule..., s. 115.

63 E. Kantorowicz, Dwa ciała..., s. 21. Warto pamiętać, że - jak podkreśla Andreas Höfele Kantorowicz interpretuje Ryszarda II dość wybiórczo, w zasadzie pomijając dwa pierwsze akty. Zob. A. Höfele, No Hamlets..., s. 111-112. Na temat szekspirowskich reprezentacji ciał politycznych zob. Shakespeare and the Body Politic, red. J. Dobski, D. Gish, Lexington Books, Lanham 2013.

64 W. Shakespeare, Ryszard II, przeł. P. Kamiński, red. A. Cetera, Wydawnictwo Uniwersytetu Warszawskiego, Warszawa 2009, s. 130.

65 Por. R. Halpern, The King's Two Buckets..., s. 67-76.

66 W. Shakespeare, Ryszard II, przeł. P. Kamiński, s. 130. 
Dzierżawcą Anglii jesteś dziś, nie królem,

Nie prawem świętym, lecz wasalem prawa ${ }^{67}$.

Być może subwersyjny przekaz Ryszarda II wynika nie tylko z sugestii, że władza królewska jest zbywalna, a godność - odwracalna, lecz również $\mathrm{z}$ implikacji, że dobro państwa (common wealth) jest rozdzielne od osoby władcy i wobec niego nadrzędne ${ }^{68}$. Król, który sprzeniewierza się obowiązkowi dbania o dobrobyt królestwa przestaje być prawowitym władcą. Jan z Gandawy wskazuje, że klęska Ryszarda II jako króla powoduje poniżenie nie tylko kraju, ale także ludzi, którzy go zamieszkują:

Ten kraj najdroższych ludzi, kraj najdroższy -

On go wyprzedał [...],

W pacht oddał niczym grzędę czy pastwisko ${ }^{69}$.

Rządy króla zmieniają życie mieszkańców królestwa, ale też poddani wpływają na losy króla. Tę współzależność w czasach elżbietańskich Raphael Holinshed sformułował następująco: „Nie może mieć biedny król bogatych poddanych i nie może też bogaty król mieć biednych"70. Ich wzajemną relację reguluje prawo, którego król ma być uosobieniem i gwarantem, władzę zaś rozstrzygania o tym, czy król sprzeniewierzył się prawu, mają jego poddani ${ }^{71}$.

Cały dramat Ryszard II jest zorganizowany wokół motywu podwojenia i antytezy. Szekspir obrazuje sytuację, w której fikcja jedności dwóch ciał rozpada się i stają się one przeciwieństwami, między którymi rozdar-

67 Ibidem, s. 98. Por. też: D. Armitage, Shakespeare's Properties, w: Shakespeare and Early Modern Political Thought, red. D. Armitage, C. Condren, A. Fitzmaurice, Cambridge University Press, New York 2009, s. 25-43.

68 P. Raffield, Shakespeare's Imaginary Constitution. Late Elizabethan Politics and the Theatre of Law, Hart Publishing, Oxford 2010, s. 82-116.

69 W. Shakespeare, Ryszard II, przeł. P. Kamiński, s. 96.

70 R. Holinshed, The Third Volume of Chronicles, J. Harison et al., London 1587, sig. Ttiiir. Cyt. za: D. Hamilton, The State of Law in "Richard II", „Shakespeare Quarterly” 1983, t. 34, nr 1, s. 8. Zdaniem Hamilton formułowane tu postulaty bliskie są poglądom Thomasa Smitha wyrażonym w De Republica Anglorum (1583).

71 W sztuce sygnałem problematycznej relacji Ryszarda II z prawem jest pojedynek sądowy, który ma rozstrzygnąć konflikt między możnymi, a który król w ostatniej chwili król odwołuje. Por. L. Hutson, Imagining Justice..., s. 136-139. 
ty jest władca. Zderzenie przeciwstawnych pojęć w warstwie poetyckiej reprezentują oksymorony i kontrastujące ze sobą elementy obrazowania. Najpierw zarzuty, które stawia królowi Jan z Gandawy opierają się na zderzeniu tego, co święte $\mathrm{z}$ tym, co upodlone ${ }^{72}$. Potem wykorzeniony z królewskiej godności Ryszard gwałtownie oscyluje między skrajnościami: widzi siebie jako bałwana w koronie, aby za chwilę porównać się do Chrystusa, po czym znowu zdegradować się do roli zdrajcy królestwa:

Muszę i siebie stawiać w liczbie zdrajców.

Przecież wam w duszy pozwoliłem na to,

By ciało króla mistyczne obnażyć,

Chwałę poniżyć, zniewolić potęgę,

Tron wepchnąć w jarzmo, państwo w gnój i słomę $e^{73}$.

Mamy tu więc do czynienia nie tyle z podwojeniem królewskich ciał, ile z rozdwojeniem tożsamości: człowiek i król będą toczyć walkę w Ryszardzie aż do jego śmierci. Przeciwieństwami są także Ryszard oraz jego kuzyn, oponent i następca, Henryk Bolingbroke. O ile Ryszard jest próżny, chwiejny i manipulowany przez pochlebców, o tyle Henryk jawi się jako wyznawca Realpolitik, który potrafi zawierać sojusze, negocjować, skutecznie osiągać cele. Żaden z nich nie jest jednak zdolny do osiągnięcia jedności dwóch ciał, jeśli definiujemy ją jako stan harmonii między królem i królestwem. Jan z Gandawy zarzuca Ryszardowi, że jest głową chorego ciała politycznego:

Ja choruję, bo widzę, żeś chory.

Masz ten kraj cały za łoże boleści. [...]

Oddałeś swoje namaszczone ciało

W ręce lekarzy, co je zarazili ${ }^{74}$.

Ale obalenie Ryszarda nie uzdrowi Anglii. Tyrana zastępuje na tronie uzurpator ${ }^{75}$. „Dokładnie wiecie, / Jak chore ciało naszego królestwa"76,

72 W. Shakespeare, Ryszard II, przeł. P. Kamiński, s. 94-99.

73 Ibidem, s. 163.

74. Ibidem, s. 98.

75 Por. W. Benjamin, Źródta dramatu..., s. 74.

76 W. Shakespeare, Henryk IV. Część druga, przeł. L. Ulrich, w: idem, Dzieła..., t. 3, s. 362. 
mówi Henryk IV udręczony zarówno przez wysiłki legitymizacyjne, jak i przez poczucie winy. Jeśli przyjąć typologię nieprawych władców, którą proponuje Hamlet, Ryszard II byłby królem bez ciała - prawowitym władcą niezdolnym do sprawowania sprawiedliwej władzy, a Henryk to król, który "jest rzeczą"77: władcą skutecznym, ale pozbawionym prawa do królewskiej godności. Nietrudno dostrzec analogię między postacią uzurpatora-królobójcy a dziadkiem Elżbiety, Henrykiem VII Tudorem. Sam Plowden w traktacie sukcesyjnym z 1566 roku dowodził, że Henryk Tudor objął tron bezprawnie: „choć mianował się królem i poddani go za króla przyjęli, jednak wedle prawa nie był królem"78. Dopiero podczas pierwszej sesji parlamentu sędziowie uznali jego władzę, de facto przyznając, że uzurpacja jest jedną $\mathrm{z}$ dróg do tronu. Opisywana przez Plowdena sukcesja wydaje się dosłowną ilustracją maksymy Henry'ego Branctona lex facet regem (prawo czyni króla ${ }^{79}$. Aby się stać figuratywnym wcieleniem prawa, król musiał najpierw zostać przez prawo uznany. Uwidacznia się kolejny paradoks obecny w pojęciu dwóch ciał: śmiertelne ciało króla pochodzi od Boga, a nadnaturalne ciało polityczne jest konstruktem ludzkim. Edward Coke stwierdził:

Ciało naturalne [...] jest stworzeniem Boga Wszechmogącego i jest poddane śmierci [...] ciało polityczne [...] [jest] ograniczone polityką człowieka [...] i pod tym względem Król uważany jest za nieśmiertelnego ${ }^{80}$.

Metafora dwóch ciał w czasach Tudorów jawi się więc jako retoryczny wybieg służący legitymizacji władców o kwestionowanych prawach do tronu, jako metoda inscenizowania godności, która została nieodwracalnie utracona ${ }^{81}$.

77 W. Shakespeare, Hamlet, przeł. J. Iwaszkiewicz, w: idem, Dwanaście dramatów, t. 2, Świat Książki, Warszawa 1999, s. 543.

78 „Althoughe he took himself kinge, and the people accepted him so, yet he was no kinge in the lawe". E. Plowden, A Treatise of the Two Bodies of the King, British Library, sygn. Harley 849, s. 31. Cyt. za: D. Majumder, Tyranny and Usurpation. The New Prince and Lawmaking Violence in Early Modern Drama, Liverpool University Press, Liverpool 2019, s. 162.

79 E. Kantorowicz, Dwa ciata..., s. 122. Por. też: K. Shoemaker, The King's Two Bodies as Lamentation, „Law, Culture and the Humanities” 2014, s. 1-12; A. Haverkamp, Richard II, Bracton, and the End of Political Theology, „Law and Literature” 2004, t. 16, nr 3, s. 313-326.

80 E. Coke, Calvins' Case (1608), w: idem, The Reports, t. 7, Rivington, London 1777, s. 10. Cyt. za: E. Kantorowicz, Dwa ciata ..., s. 334.

81 Por. K. Shoemaker, The King's Two Bodies..., s. 8-12; R. Halpern, The King's Two Buckets..., s. 74-75. 
Szekspirowski Ryszard II jest metafikcją: fikcją literacką, której nadrzędnym tematem jest fikcja jedności dwóch ciał króla. Na oczach widza owa podwójna, naśladująca prawdę fikcja „zaczyna się dezintegrować, a jego transcendentna «rzeczywistość», jego obiektywna prawda i podobne boskiemu istnienie, przed chwilą tak wspaniałe, blaknie, jest zaledwie nomen" ${ }^{82}$. W efekcie władza staje się wręcz tożsama ze śmiercią, a wspólnotowe ciało jest sumą cierpień zmarłych monarchów. Mówi Ryszard:

Na miłość Boską, siądźmy tutaj w koło,

By snuć opowieść o zabitych królach. [...]

Wszyscy pomordowani. Bo w obręczy,

Którą śmiertelne czoło króla spięto

Śmierć trzyma dwór błazeński ${ }^{83}$.

Korona niszczy więc królów, a ciało naturalne władcy jest ukazane jako zakładnik ciała politycznego - zakładnik, który po wyjściu z niewoli jest nieodwracalnie złamany. O ile Kantorowicz przedstawia relację dwóch ciał z perspektywy ciała politycznego, o tyle Szekspir rysuje poruszający obraz tej relacji z perspektywy ciała naturalnego. Bodaj najdobitniej czyni to w drugiej części Henryka IV, w której porównuje koronę - emblemat ciała politycznego - do zbroi noszonej w gorący letni dzień:

O, majestacie! Temu, kto cię nosi,

Jesteś jak zbroja kosztowna w upale,

Która go piecze, dając bezpieczeństwo ${ }^{84}$.

Ciało polityczne jest zatem czymś, co zapewnia ochronę, ale jednocześnie stanowi źródło udręki. W oryginale brzmi to jeszcze dobitniej: korona „parzy bezpieczeństwem” (scalds with safety) człowieka, który ją nosi, jest więc de facto narzędziem tortur dla ciała naturalnego. W Ryszardzie II w miarę, jak dezintegruje się ciało polityczne władcy, obnaża się jego śmiertelne ciało naturalne, pozbawione nawet pozoru siły. Można zatem czytać Ryszarda II jako sztukę reprezentującą teatralne mechanizmy władzy. Szekspirowski Ryszard to król-aktor, który odgrywa swą tożsamość, a raczej współistniejące w nim, sprzeczne tożsamości. Wyznaje: 
W wielu przywdziewam się ludzi,

A w każdym źle mi ${ }^{85}$.

W oryginale królewska deklaracja jeszcze mocniej akcentuje teatralność: Thus play I in one person many people, / And none contented ${ }^{86}$. Królowanie jest więc rolą odgrywaną przez Ryszarda - rolą, z której można wyjść czy raczej wypaść:

Czasem jestem królem,

Ale zdradzonym, więc chcę być żebrakiem,

I oto jestem. Ale nędza dławi,

Więc myślę, że królowi było lepiej,

I znów króluję. Ale już po chwili

Bolingbroke znowu mnie odkrólowuje,

I jestem niczym ${ }^{87}$.

Stanowiąca apogeum konfliktu dramatycznego scena abdykacji jest lustrzanym odbiciem przysięgi koronacyjnej: solenną litanią powtórzeń Ryszarda, który, nawet oddając koronę, nie potrafi przestać być królem. Ryszard nie tyle zrzeka się korony, ile dokonuje ceremonialnego „odkrólowania" ${ }^{88}$. Nawet kiedy traci wszystko, wciąż sięga po sceniczne rekwizyty, by eskalować napięcie i inscenizować - choćby przed sobą samym - dramatyzacje swojego losu. Pozbawiony korony, daje wyraz gwałtownie postępującemu procesowi rozszczepienia królewskich osobowości. Role, między którymi balansuje, można czytać jako metonimię dwóch ciał: król to ciało polityczne, a żebrak - ciało naturalne monarchy. Wyjście z roli króla wiąże się z przemocą i pociąga za sobą zniszczenie. Dokonuje się implozja tożsamości władcy, który nie czuje się już ani królem, ani człowiekiem, a staje się bezimienną istotą o niejasnym statusie:

Jestem bez tytułu,

Nie mam nazwiska $[\ldots]$

Wszystko wydarte. [...]

86 W. Shakespeare, King Richard II, red. A. Gurr, Cambridge University Press, Cambridge1984, s. 177.

87 W. Shakespeare, Ryszard II, przeł. P. Kamiński, s. 191.

88 Ibidem, s. 162. 
Zim przeżyć tyle, a jeszcze nie wiedzieć,

Jakim się teraz nazywać imieniem! ${ }^{19}$.

Pierwsza prośba Ryszarda po oddaniu insygniów władzy brzmi:

Niech mi czym prędzej przyniosą zwierciadło,

Chcę wiedzieć, ile twarzy mi zostało,

Odkąd majestat jej poszedł z torbami ${ }^{90}$.

Można w tym widzieć przejaw narcyzmu króla, ale w kontekście naszych rozważań lepiej chyba opisać tę scenę jako konfrontację króla z własnym wizerunkiem, od kilku chwil już niekrólewskim. Swoją twarz Ryszard uważa za emblemat monarchii, więc tracąc władzę, powinien też stracić twarz. Patrząc w lustro, mówi:

To jest słońce,

Przed którym wszyscy z was mrużyli oczy? [...]

Proszę, rozpadło się na sto kawałków!

Milczący królu, taki morał z tego,

Że rozpacz szybko moją twarz rozbiła ${ }^{91}$.

Scena rozbicia lustra symbolicznie kończy panowanie Ryszarda II. Warto odnotować, że inspiracją dla Szekspirowskiego tekstu mogło być Zwierciadło dla zarzadzajacych (The Mirror for Magistrates), powstały w czasach Tudorów tekst zbiorowego autorstwa. Dzieje Ryszarda II stanowią w nim exemplum złych rządów (evyll governaunce) ${ }^{92}$ i przestrogę przed sięganiem po absolutyzm. Pogarda dla prawa i kierowanie się emocjami ( $\mathrm{am}$ a King that ruled all by lust ${ }^{93}$ ) definiują Ryszarda jako tyrana ${ }^{94}$, który zaraził ciało polityczne chorobą. Jeśli wierzyć kronice Raphaela Holinsheda,

89 W. Shakespeare, Ryszard II, przeł. L. Ulrich, w: idem, Dzieła dramatyczne, t. 1, Nakład Gebethnera i Spółki, Kraków 1895, s. 148-149.

90 W. Shakespeare, Ryszard II, przeł. P. Kamiński, s. 164.

91 Ibidem, s. 165.

92 The Mirror for Magistrates, red. L.B. Campbell, Cambridge University Press, London 1938, s. 111. Por. J. Winston, A Mirror for Magistrates and Public Political Discourse in Elizabethan England, „Studies in Philology” 2004, t. 101, nr 4, s. 381-400.

93 The Mirror for Magistrates..., s. 113.

94 Szekspirowski Henryk V mówi, „Nie jestem tyran, lecz król chrześcijański; / Namiętność moja jest w mej woli więzach". W. Shakespeare, Henryk V, przeł. L. Ulrich, w: idem, Dzieła..., t. 3, s. 443. 
przed Parlamentem odczytano akt detronizacji, w którym postawiono Ryszardowi zarzut, że posługiwał się prawem dla własnych korzyści, a przez to „niszczył szlachtę, a biedny gmin doprowadził do nędzy” ${ }^{95}$. Król, który sprzeniewierzył się obowiązkom wobec państwa, stał się wrogiem sprawiedliwości, nie jej uosobieniem. I właśnie sprawiedliwość - na poziomie postulatywnym tożsama z pojęciem ciała politycznego - jest argumentem uprawomocniającym bunt wobec władzy, a nawet królobójstwo.

Porównanie Elżbiety do Ryszarda II ma głębsze podstawy niż udział szekspirowskiej kompanii teatralnej w buncie Essexa. Od lat osiemdziesiątych XVI wieku - a więc dwadzieścia lat wcześniej, nim Elżbieta publicznie utożsami się z Ryszardem II - jego imieniem posługiwano się jako złośliwym przydomkiem królowej ${ }^{96}$. Analogie między ich rządami miały polegać przede wszystkim na narzucaniu zbyt wysokich podatków, zamiłowaniu do pochlebców i problematycznej sukcesji. Francis Knollys w liście skarży się, że królowa, tak jak Ryszard II, nie słucha przestróg i z niechęcią traktuje tych, którzy ją przestrzegają. Zamiast tego woli się otaczać przytakującymi jej faworytami - Knollys nazywa ich Richard II's men ${ }^{97}$. Tego samego wyrażenia używa Henry Carey, kiedy tłumaczy, dlaczego nie zrobił kariery na dworze: „nie należałem nigdy do ludzi Ryszarda II”98. W 1599 roku ukazała się rozprawa Johna Haywarda zatytułowana The Life and Reigne of Henry IV, w której opis panowania Ryszarda II jest w istocie krytyczną parabolą rządów Elżbiety. Autor zadedykował książkę Essexowi, porównując go do Henryka IV, co dodatkowo wyostrzyło jego krytyczne intencje. Dwór odczytał je bezbłędnie i postawił Haywardowi zarzut zdrady. Wprawdzie główne przewinienie, którego się dopatrzył przesłuchujący

\footnotetext{
95 R. Holinshed, fol. 303r. Cyt. za: D. Hamilton, The State of Law..., s. 8.

96 E.M. Albright, Shakespeare's Richard II and the Essex Conspiracy, „PMLA” 1927, nr 3, s. 686$-720$.

97 Queen Elizabeth and Her Times. A Series of Original Letters, t. 2, red. T. Wright, wyd. H. Colburn, London 1838, s.75.

98 Lives of the Queens of England, t. 3, red. A. Strickland, wyd. Lea and Blanchard, Philadelphia 1852, s. 540.
} 
go Francis Bacon, polegało na licznych plagiatach z Tacyta, jednak Hayward został uwięziony i wyszedł na wolność dopiero po śmierci Elżbiety99.

Analogia między Elżbietą a Ryszardem II jest jednak głębsza, niż to wynika z historycznej anegdoty. Niezależnie od - mniej czy bardziej powierzchownych - podobieństw ich rządów, Elżbieta istotnie była Ryszardem II w dwojakim sensie. Po pierwsze - ze względu na tożsamość ciała politycznego, pojmowanego jako wspólnota przeszłych i przyszłych królów, uobecniana przez króla aktualnie rządzącego. Ponieważ „król nigdy nie umiera", Elżbieta, w myśl teorii dwóch ciał króla, jest tym samym monarchą, którym był wcześniej Ryszard II. Po drugie - możemy uznać Ryszarda II za ucieleśnienie fikcjonalnego aspektu dwóch ciał, to znaczy immanentnej sprzeczności między człowieczeństwem a koroną. W takim wypadku każdy władca jest potencjalnie Ryszardem II, każdy nosi w sobie tę sprzeczność, która uwidacznia się zwłaszcza w chwilach kryzysu, jak w ostatniej dekadzie rządów Elżbiety I. Jeśli zatem Elżbieta była Ryszardem II, to przede wszystkim jako władca, którego ciało naturalne stało się zakładnikiem ciała politycznego.

Z Szekspirowskich kronik wyłania się obraz Ryszarda II jako uosobionego paradoksu, istoty złożonej z nierozstrzygalnych sprzeczności: jest monarchą o niekwestionowanym prawie do tronu, które to prawo zostało zakwestionowane, tyranem i męczennikiem. Paradoks uosabiany przez Ryszarda II - na pozór będący zaprzeczeniem teorii dwóch ciał - został do niej inkorporowany. Niespełna pięćdziesiąt lat po śmierci Elżbiety purytańska opozycja wypowiedziała wojnę Karolowi I. W 1649 roku król został zdetronizowany i skazany na śmierć jako zdrajca stanu. Akt królobójstwa został wówczas uprawomocniony jako działanie nie tylko nieprzynoszące szkody ciału politycznemu, ale wręcz jako jego obrona: należało zabić króla, by Król mógł żyć. Teoria dwóch ciał w tym kontekście jawi się jako jedyny dostępny człowiekowi triumf nad śmiercią: poprzez tworzenie fikcji ${ }^{100}$.

99 Zob. E.M. Albright, Shakespeare's Richard II..., s. 700.

100 Por. S. Greenblatt, Fifty Years of The King's Two Bodies, „Representations” 2009, t. 106, nr 1, s. 64-65. 


\section{Bibliografia}

Albright E.M., Shakespeare's Richard II and the Essex Conspiracy, „PMLA” 1927, nr 3.

Armas F.A. de, The Return of Astraea. An Astral-Imperial Myth in Calderón, The University Press of Kentucky, Lexington 1986.

Armitage D., Shakespeare's Properties, w: Shakespeare and Early Modern Political Thought, red. D. Armitage, C. Condren, A. Fitzmaurice, Cambridge University Press, New York 2009.

Ashby R., "Pierced to the Soul”. The Politics of the Gaze in "Richard II”, "Shakespeare" 2015, t. 11, nr 2.

Axton M., The Influence of Edmund Plowden's Succession Treatise, „Huntington Library Quarterly” 1974, t. 37, nr 3.

Axton M., The Queen's Two Bodies. Drama and the Elizabethan Succession, Royal Historical Society, London 1977.

Benjamin W., Źródła dramatu żałobnego w Niemczech, przeł. A. Kopacki, Wydawnictwo Sic!, Warszawa 2013.

Bloch M., Królowie cudotwórcy. Studium na temat nadprzyrodzonego charakteru przypisywanego władzy królewskiej zwłaszcza we Francji i w Anglii, przeł. J.M. Kłoczowski, Volumen - Bellona, Warszawa 1998.

Booth T., A Body Politic to Govern. The Political Humanism of Elizabeth I, Cambridge Scholars Publishing, Newcastle upon Tyne 2013.

Chronicles of the Revolution, 1397-1400. The Reign of Richard II, red. C. Given-Wilson, Manchester University Press, Manchester 1993.

Clare J., The Censorship of the Deposition Scene in "Richard II”, "The Review of English Studies" 1990, t. 41.

Clegg C.S., "By the Choise and Inuitation of al the Realme”. "Richard II” and Elizabethan Press Censorship, "Shakespeare Quarterly” 1997, t. 48, nr 4.

Coke E., Calvins' Case (1608), w: idem, The Reports, t. 7, Rivington, London 1777.

Doran S., The Queen, w: The Elizabethan World, red. S. Doran, N. Jones, Routledge, London 2011.

Doty J.S., Shakespeare's Richard II. "Popularity”, and the Early Modern Public Sphere, „Shakespeare Quarterly” 2010, t. 61, nr 2.

Elizabeth I, Collected Works, red. L.S. Marcus, J. Mueller, M.B. Rose, University of Chicago Press, Chicago 2000.

[An] English Chronicle of the Reigns of Richard II, Henry IV, Henry V, and Henry VI, red. J.S. Davies, Camden Society, London 1856.

Frye S., Elizabeth I. The Competition for Representation, Oxford University Press, Oxford 1993. 
Geertz C., Centra, królowie, charyzma, w: idem, Wiedza lokalna. Dalsze eseje $z$ zakresu antropologii interpretatywnej, przeł. D. Wolska, Wydawnictwo Uniwersytetu Jagiellońskiego, Kraków 2005.

Greenblatt S., Fifty Years of The King's Two Bodies, „Representations” 2009, t. 106, nr 1.

Greenblatt S., Niewidzialne kule. Wtadza i jej obalenie w dobie rensesansu, przeł. J. Sadowska, A. Szwach, K. Williams, „Dialog” 2010, nr 5 (55).

Halpern R., The King's Two Buckets. Kantorowicz, Richard II, and Fiscal Trauerspiel, „Representations” 2009, t. 106, nr 1.

Hamilton D., The State of Law in "Richard II", „Shakespeare Quarterly" 1983, t. 34, nr 1 .

Hammer P.E.J., Shakespeare's Richard II. The Play of 7 February 1601, and the Essex Rising, „Shakespeare Quarterly” 2008, t. 59, nr 1.

Hartley T.E., Proceedings in the Parliaments of Elizabeth I, t. 1, Leicester University Press, Leicester 1981.

Haverkamp A., Richard II, Bracton, and the End of Political Theology, „Law and Literature" 2004, t. 16, nr 3.

Herrero M., On Political Theology. The Hidden Dialogue between C. Schmitt and Ernst H. Kantorowicz in "The King's Two Bodies”, „History of European Ideas" 2015, t. 41, nr 8.

Hethe, Archebishoppe of Yorke His Oration Made in the Parliament House, 1559, w: Annals of the Reformation and Establishment of Religion, and Other Various Occurrences in the Church of England, during Queen Elizabeth's Happy Reign, red. J. Strype, Clarendon, Oxford 1824.

Höfele A., No Hamlets, German Shakespeare from Friedrich Nietzsche to Carl Schmitt, Oxford University Press, Oxford 2016.

Hutson L., Imagining Justice, Kantorowicz and Shakespeare, „Representations” 2009, t. 106, nr 1 .

Hutson L., Not the King's Two Bodies. Reading the „Body Politic” in Shakespeare's Henry IV, cz. 1-2, w: Rhetoric and Law in Early Modern Europe, red. V.A. Kahn, L. Hutson, Yale University Press, New Haven 2001, s. 168.

[The] Image and Perception of Monarchy in Medieval and Early Modern Europe, red. S. McGlynn, E. Woodacre, Cambridge Scholars Publishing, Newcastle upon Tyne 2014.

Jakub VI Stuart, Basilikon Doron, przeł. M. Misztal, Wydawnictwo Naukowe Akademii Pedagogicznej, Kraków 2006.

Jan z Salisbury, Policraticus, przeł. M. Kruk, Verba, Lublin 2008.

Johnson P., Elizabeth I. A Study in Power and Intellect, Weidenfeld \& Nicholson, London 1974. 
Kahn V., Political Theology and Fiction, „Representations” 2009, nr 1.

Kantorowicz E., Dwa ciała króla. Studium ze średniowiecznej teologii politycznej, przeł. M. Michalski, A. Krawiec, Wydawnictwo Naukowe PWN, Warszawa 2007.

Keyishian H., Punishment Theory in the Renaissance. The Law and the Drama, w: Shakespeare and the Law, red. P. Raffield, G. Watt, Hart Publishing, Oxford 2008.

Kizelbach U., The Pragmatics of Early Modern Politics. Power and Kingship in Shakespeare's History Plays, Rodopi, Amsterdam - New York 2014.

Knox [J. Knox], First Blast of the Trumpet against the Monstrous Regiment of Women, w: The Works of John Knox, [J. Crespin, Geneva] 1558.

Lambarde W., Eirenarcha, or of the Office of the Iustices of Peace in two Bookes, Imprinted by Newbery, and Bynneman, London 1581.

Levin C., The Heart and Stomach of a King. Elizabeth I and the Politics of Sex and Power, The University of Pennsylvania Press, Philadelphia 1994.

Levine M., The Early Elizabethan Succession Question, 1558-1568, Stanford University Press, Stanford 1966.

Lives of the Queens of England, t. 3, red. A. Strickland, wyd. Lea and Blanchard, Philadelphia 1852.

Majumder D., Tyranny and Usurpation. The New Prince and Lawmaking Violence in Early Modern Drama, Liverpool University Press, Liverpool 2019.

McLaren A.N., Political Culture in the Reign of Elizabeth I. Queen and Commonwealth 1558-1585, Cambridge University Press, Cambridge 2004.

[The] Mirror for Magistrates, red. L.B. Campbell, Cambridge University Press, London 1938.

Montrose L., "Shaping Fantasies”. Figurations of Gender and Power in Elizabethan Culture, w: Representing the English Renaissance, red. S. Greenblatt, University of California Press, Berkeley 1988.

Montrose L., Elizabeth through the Looking Glass. Picturing the Queen's Two Bodies, w: The Body of the Queen, Gender and Rule in the Courtly World, 1500-2000, red. R. Schulte, Berghahn Books, New York 2006.

Montrose L., The Subject of Elizabeth, The University of Chicago Press, Chicago 2006.

Nichols J., Progresses, Public Processions of Queen Elizabeth, t. 3, J. Nichols and Son, London 1823.

Norbrook D., The Emperor's New Body? "Richard II”, Ernst Kantorowicz, and the Politics of Shakespeare Criticism, „Textual Practice” 1996, nr 10. 
Norbrook D., A Liberal Tongue, Language and Rebellion in "Richard II", w: Shakespeare's Universe. Renaissance Ideas and Conventions. Essays in Honour of W.R. Elton, red. J. M. Mucciolo, S. J. Doloff, E. A. Rauchert, Scholar's Press, Aldershot 1996.

Nugae Antiquae Being a Miscellaneous Collection of Original Papers, in Prose and Verse, t. 1, red. J. Harrington, Vernor and Hood, London 1804.

Orgel S., Illusion of Power, University of California Press, Berkeley 1974.

Plowden E., A Treatise of the Two Bodies of the King, British Library, sygn. Harley 849, s. 31.

Plowden E., Commentaries or Reports, S. Brooke, London 1816.

Post Walton K., The English Succession Crisis and Debates about Mary Stewart. Law, National Identity, Citizenship and the Queen's Two Bodies, w: eadem, Catholic Queen, Protestant Patriarchy, Palgrave Macmillan, London 2007.

Practices and Treasons Attempted and Committed by Robert, Earl of Essex, and His Complices, London 1601, fol. K3r.

Queen Elizabeth and Her Times; a Series of Original Letters, t. 2, red. T. Wright, wyd. H. Colburn, London, 1838.

Raffield P., Law and the Equivocal Image. Sacred and Profane in Royal Portraiture, w: Visualizing Law and Authority. Essays on Legal Aesthetics. Law and Literature, red. L. Dahlberg, De Gruyter, Berlin 2013.

Raffield P., Representing the Body of Law in Early Modern England, w: Performing the Renaissance Body. Essays on Drama, Law, and Representation, red. J. Drakakis, S. Fiorato, De Gruyter Verlag, Berlin 2016.

Raffield P., Shakespeare's Imaginary Constitution. Late Elizabethan Politics and the Theatre of Law, Hart Publishing, Oxford 2010.

[A] Report of her Majestie's Most Gratious Answere, Delivered by Her selfe verbally, to the First Petitions of the Lords and Commons ... the xii Day of November 1586, w: A Collection of Scarce and Valuable Tracts, t. 1, red. W. Scott, wyd. T. Cordeil and W. Davies, London 1809.

Riehl A., The Face of Queenship. Early Modern Representations of Elizabeth I, Palgrave Macmillan, New York 2010.

Rust J.R., The Body in Mystery. The Political Theology of the Corpus Mysticum in the Literature of Reformation England, Northwestern University Press, Evanston 2014.

Sale C., „The King is a Thing”. The King's Prerogative and the Treasure of the Realm in Plowden's Report of the Case of Mines and Shakespeare's Hamlet, w: Shakespeare and the Law, red. P. Raffield, G. Watt, Hart Publishing, Oxford 2008.

Saslow J.M., The Medici Wedding of 1589. Florentine Festival as Theatrum Mundi, Yale University Press, New Haven 1996. 
Schmitt C., Teologia polityczna. Cztery rozdziaty poświęcone nauce o suwerenności, w: idem, Teologia polityczna i inne pisma, przeł. M.A. Cichocki, Aletheia, Warszawa 2012.

Scott-Warren J., Was Elizabeth I Richard II? The Authenticity of Lambarde's „Conversation”, „The Review of English Studies” 2013, t. 64, nr 264.

Shakespeare and the Body Politic, red. J. Dobski, D. Gish, Lexington Books, Lanham 2013.

Shakespeare W., Hamlet, przeł. J. Iwaszkiewicz, w, idem, Dwanaście dramatów, t. 2, Świat Książki, Warszawa 1999.

[Shakespeare W.], Dzieła dramatyczne Williama Shakespeare (Szekspira) w dwunastu tomach, przeł. L. Urlich, Nakład Gebethnera i Spółki, Kraków 1895, t. 1, 3. Tu: Król Henryk IV. Część druga (t. 3); Król Henryk V (t. 3); Król Ryszard II (t. 1).

[Shakespeare W.], Król Ryszard II, w: Dzieła Williama Szekspira, przeł. S. Koźmian, red. Henryk Biegeleisen, t. 3: Dramaty królewskie, Księgarnia Polska, Lwów 1895.

Shakespeare W., King Richard II, red. A. Gurr, Cambridge University Press, Cambridge 1984, s. 177.

Shakespeare W., Ryszard II, przeł. P. Kamiński, Wydawnictwo Uniwersytetu Warszawskiego, Warszawa 2009.

Shakespeare W., Życie Henryka V, przeł. L. Ulrich, w: idem, Dzieła dramatyczne, t. 3, Państwowy Instytut Wydawniczy, Warszawa 1973.

Shenk L., Learned Queen. The Image of Elizabeth I in Politic and Poetry, Palgrave Macmillian, New York 2010.

Shoemaker K., The King's Two Bodies as Lamentation, „Law, Culture and the Humanities" 2014.

Tennenhouse L., Power on Display. The Politics of Shakespeare's Genres, Methuen, New York 1986.

Tudor Constitutional Documents. A.D. 1485-1603, red. J.R. Tanner, Cambridge University Press, Cambridge 1930.

Vyroubalová E., Wood R.J., Propping up the King's Two Bodies in „Richard II”, „Early English Studies” 2011, nr 4.

Walker G., The Politics of Performance in Early Renaissance Drama, Cambridge University Press, Cambridge 1998.

Whitelock A., The Queen's Two Bodies. The Image and Reality of the Body of Elizabeth I, w: The Image and Perception of Monarchy in Medieval and Early Modern Europe, red. S. McGlynn, E. Woodacre, Cambridge Scholars Publishing, Cambridge 2014. 
Winston J., A Mirror for Magistrates and Public Political Discourse in Elizabethan England, „Studies in Philology” 2004, t. 101, nr 4.

Yates F.A., Queen Elizabeth as Astraea, "Journal of the Warburg and Courtauld Institutes" 1947, t. 10.

\section{"Richard II is Me". The Theory of the King's Two Bodies and Elizabethan Political Practice}

The purpose of the article is to show how the doctrine of the King's Two Bodies formulated by lawyer Edmund Plowden influenced political practice and its artistic representation. It is worth emphasising that the image of the king as a one-man corporation includes an immanent conflict resulting not only from the coexistence of conflicting identities in one person, but also from the need to constantly negotiate relations between them. Therefore, the concept of two bodies could simultaneously serve as a tool for legitimising and contesting power. This paradox is well illustrated by Queen Elizabeth I's famous declaration "Richard II is Me", which has been intriguing researchers for decades and receiving extensive comments. So far it has not been placed in the context of the doctrine of the King's Two Bodies, in which it sounds probably most fully. The perspective of abolished temporality inscribed in it sheds a new light on the queen's identification with Richard II: both the historical ruler and the hero of the Shakespearean chronicle.

\section{Keywords:}

William Shakespeare, Richard II, Queen Elizabeth I,

King's Two Bodies, Ernst Kantorowicz, POWER AND AUTHORITY IN THE EARLY Modern PERIOD. 